\title{
Efisiensi Penggunaan Radiasi Matahari dan Respon Tanaman Kedelai (Glycine max L.) terhadap Penggunaan Mulsa Reflektif
}

\section{Solar Radiation Use Efficiency and Soybean (Glycine max L.) Responses to the Utilization of Reflective Mulches}

\author{
Syahrun Mubarak ${ }^{1}$ Impron $^{2 *}$, dan Tania June ${ }^{2}$ \\ ${ }^{1}$ Program Studi Klimatologi Terapan, Sekolah Pascasarjana, Institut Pertanian Bogor \\ ${ }^{2}$ Departemen Geofisika dan Meteorologi, Fakultas Matematika dan Ilmu Pengetahuan Alam \\ Gedung FMIPA Wing 19 Lv. 4 Kampus IPB Darmaga, Bogor 16680, Indonesia
}

Diterima 2 Oktober 2017/Disetujui 27 Juli 2018

\begin{abstract}
One of factors affecting the productivity of soybean crop is the availability of solar radiation. Reduction of solar radiation reaching soybean crop by cloud cover especially during rainy season or by shade of trees could potentially decrease soybean production. The availability of radiation for the crop can be increased through the use of reflective mulch to reflect back transmitted radiation to the crop canopy. This study aimed to determine the effect of shade and reflective mulch on crop solar radiation balance and crop productivity responses. A field experiment in Bogor, Indonesia in July 2016 to January 2017, was conducted, applying a Nested Design-two factors model with three replications. The first factor was two levels of shading, i.e., without and with 50\% shade; and the second factor was three levels, i.e., without mulch, black silver mulch, and metallic mulch. The results showed that the use of mulch influenced the radiation balance of plants, increasing distribution of radiation reception in plants, solar radiation interception and RUE. The use of mulch caused changes in canopy structure by increase LAI, so that the inhibited radiation was higher. The reflected radiation from the mulch increased production per plants and weight of 1,000 seeds in shaded plants.
\end{abstract}

Keywords: black silver mulch, metallic mulch, radiation balance, radiation interception, shading

\section{ABSTRAK}

Radiasi matahari merupakan salah satu penentu produktivitas tanaman kedelai. Pengurangan jumlah radiasi matahari yang sampai ke tanaman kedelai oleh penutupan awan terutama saat musim hujan atau oleh naungan tanaman berpotensi menurunkan produktivitas tanaman kedelai. Ketersediaan radiasi dapat ditingkatkan melalui penggunaan mulsa reflektif yang memantulkan radiasi yang sampai ke permukaan lahan untuk dipantulkan kembali ke tajuk tanaman. Penelitian ini bertujuan menganalisis pengaruh naungan dan mulsa reflektif terhadap neraca radiasi matahari dan produktivitas tanaman kedelai. Penelitian dilaksanakan di Bogor, Indonesia, mulai bulan Juli 2016 hingga Januari 2017 menggunakan rancangan percobaan petak tersarang (nested design) dua faktor tiga ulangan. Faktor pertama adalah naungan paranet dua taraf yaitu tanpa naungan dan naungan $50 \%$, faktor kedua adalah penggunaan mulsa sebagai reflektor radiasi matahari yang terdiri atas tiga taraf yaitu tanpa reflektor mulsa, mulsa perak hitam, dan mulsa metalik. Hasil penelitian menunjukkan bahwa penggunaan mulsa mampu mempengaruhi neraca radiasi tanaman dengan meningkatkan distribusi penerimaan radiasi pada tanaman, nilai intersepsi radiasi surya dan efisiensi penggunaan radiasi (RUE). Penggunaan mulsa mengakibatkan perubahan struktur kanopi melalui peningkatan indeks luas daun (ILD) sehingga radiasi yang diredam semakin tinggi. Adanya radiasi yang dipantulkan oleh permukaan mulsa dapat meningkatkan produksi tanaman dan bobot 1,000 biji pada tanaman yang ternaungi atau kondisi radiasi rendah.

Kata kunci: mulsa perak hitam, mulsa metalik, neraca radiasi, naungan, intersepsi radiasi

\section{PENDAHULUAN}

Kedelai merupakan salah satu komoditas penting yang terus dikembangkan karena mengandung gizi yang

\footnotetext{
* Penulis untuk korespondensi. e-mail: impron@gmail.com
}

baik untuk kebutuhan manusia. Produktivitas tanaman kedelai sangat dipengaruhi oleh ketersediaan radiasi surya. Kurangnya radiasi yang sampai pada tanaman dapat mempengaruhi pertumbuhan dan perkembangan tanaman. Rendahnya radiasi matahari yang sampai pada tanaman bisa disebabkan adanya naungan pepohonan, sehingga 
radiasi matahari tereduksi oleh kanopi pepohonan tersebut. Tanaman yang ternaungi akan mengalami penurunan ketebalan daun, klorofil pada daun, dan mengganggu laju fotosintesis (Muhuria, 2007).

Penerimaan radiasi juga erat kaitannya dengan faktor musim. Pada musim hujan, nilai curah hujan dan keawanan menjadi meningkat serta lama penyinaran menjadi lebih singkat, sehingga wilayah dengan keawanan yang tinggi bisa berpotensi mengalami penurunan produksi dan produktivitas. Radiasi matahari optimum yang dibutuhkan tanaman untuk melakukan proses fotosintesis adalah sekitar 209.3-558.2 W. $\mathrm{m}^{-2}$ dan fotosintesis maksimum pada intensitas cahaya $300 \mathrm{~W} \cdot \mathrm{m}^{-2}$ (White dan Izquerdo, 1993). Tanaman kedelai tumbuh lebih sensitif terhadap PAR (Photosynthetically Active Radiation) dalam kondisi dimana cahaya sedikit tersedia (Feng et al., 2014). Peningkatan produksi kedelai linier dengan peningkatan intersepsi cahaya dan konversi energinya (Koester et al., 2014; Gitelson dan Gamon, 2015).

Energi radiasi yang dipancarkan oleh matahari tidak semua sampai ke permukaan, dari $100 \%$ radiasi yang dipancarkan oleh matahari, hanya $48-50 \%$ yang sampai secara langsung ke permukaan dan yang bisa dimanfaatkan hanya pada panjang gelombang tertentu (NASA Earth Observatory, 2008). Radiasi yang sampai pada tanaman diefisienkan untuk tumbuh, berkembang dan melakukan produksi sedangkan beberapa dipantulkan dan ditansmisikan ke permukaan. Transmisi radiasi dipengaruhi oleh struktur kanopi, jenis tanaman, ukuran luas daun, angin dan sudut datang matahari. Oleh sebab itu defisit radiasi yang disebabkan oleh faktor naungan dan kondisi atmosfer dapat mempengaruhi distribusi radiasi surya dan memberikan respon terhadap tanaman (Feng et al., 2014).

Radiasi matahari mempunyai sifat merambat dan dapat dipantulkan, sehingga radiasi yang ditransmisikan ke permukaan dapat dimanfaatkan oleh tanaman dengan adanya reflektivitas permukaan. Adanya distribusi radiasi dari permukaan diharapkan mampu meningkatkan intersepsi radiasi dan efisiensi penggunaan radiasi pada tanaman. Meyer et al. (2012) dan Mejias (2012) dalam penelitiannya menemukan bahwa terjadi peningkatan hasil tanaman yang positif karena adanya tambahan radiasi pantulan yang sampai ke tanaman.

Tujuan penelitian ini adalah menentukan pengaruh penggunaan naungan dan mulsa reflektif terhadap neraca radiasi surya serta pengaruhnya terhadap pertumbuhan dan produktivitas tanaman kedelai.

\section{BAHAN DAN METODE}

Penelitian dilaksanakan pada lahan percobaan Kelurahan Situgede, Kecamatan Dramaga, Kabupaten Bogor, Jawa Barat pada bulan Juli 2016 sampai Januari 2017. Bahan dan alat yang digunakan pada penelitian ini diantaranya adalah benih kedelai varietas Anjasmoro, mulsa dari plastik, paranet, solarimeter, data logger, dan mikrokontroler.
Penelitian berbentuk modifikasi radiasi matahari pada tanaman kedelai dengan skenario pemberian naungan paranet yang dapat menghambat radiasi dan reflektor mulsa yang berfungsi memantulkan kembali cahaya matahari ke bagian tanaman. Penelitian disusun dalam rancangan petak tersarang (nested design) dua faktor dan tiga ulangan. Faktor pertama adalah naungan dari paranet dua taraf, yaitu tanpa naungan $(\mathrm{N}-0 \%)$ dan naungan $50 \%(\mathrm{~N}-50 \%)$. Faktor kedua adalah penggunaan mulsa sebagai reflektor radiasi matahari yang terdiri atas tiga taraf yaitu tanpa mulsa (M-0), mulsa perak hitam (MP-PH) dan mulsa metalik (MP-MA).

Data yang diperoleh dianalisis dengan sidik ragam dan diuji dengan DMRT (Duncan Multiple Range Test) pada taraf kepercayaan 95\% menggunakan program SPSS. Analisis regresi sederhana digunakan untuk mengetahui hubungan antara dua variabel serta untuk memprediksi nilai dari variabel dependen apabila nilai variabel independen mengalami kenaikan atau penurunan.

Neraca radiasi diukur menggunakan tube solarimeter yang telah dikalibrasi dengan solarimeter standar dan tersambung dengan data logger yang dilengkapi mikrokontroler. Mikrokontroler memungkinkan data terekam secara otomatis pada frekuensi pengukuran tertentu. Data terekam dan tersimpan setiap 4 menit setiap hari selama penelitian berlangsung untuk memperoleh data radiasi matahari dengan variasi jam dan variasi harian. Pengukuran dilakukan di atas dan di bawah tajuk tanaman. Pengukuran juga dilakukan terhadap radiasi matahari yang dipantulkan oleh permukaan mulsa menggunakan sensor dengan posisi terbalik. Pengukuran data secara manual dilakukan menggunakan solarimeter yang disambung dan terekam dalam Droid term untuk menghindari adanya sensor yang tidak merekam data. Hasil pengukuran neraca radiasi kemudian diverifikasi dengan data pengukuran yang diperoleh dari stasiun BMKG.

Intersepsi radiasi surya merupakan besar radiasi surya yang tertahan oleh tajuk atau kanopi tanaman yang tidak sampai ke permukaan tanah di bawah tajuk atau kanopi tanaman tersebut. Intersepsi radiasi surya adalah selisih antara radiasi yang diterima di atas tajuk dan di bawah tajuk tanaman. Qint $=\mathrm{Q}_{0}-\mathrm{Q}$ di mana nilai $\mathrm{Q}=$ radiasi yang diterima di bawah tajuk $\left(\mathrm{MJ} \mathrm{m}^{-2}\right), \mathrm{Q}_{0}=$ Radiasi yang diterima di atas tajuk $\left(\mathrm{MJ}_{\mathrm{m}} \mathrm{m}^{-2}\right)$. Persamaan lain untuk menduga intersepsi radiasi adalah persamaan berdasarkan Hukum Beer yang digunakan (Handoko et al., 2010) yaitu Qint = Q0 x (1 - exp(-k x ILD)), ILD = (Ld/Lh) x Jp d a n $\mathrm{k}=\ln (\mathrm{Q} / \mathrm{Qt}) /$ ILD. Nilai $\mathrm{k}=$ koefisien pemadaman, Jp merupakan jumlah populasi, ILD = Indeks luas daun $\left(\mathrm{m}^{2}\right.$ $\left.\mathrm{m}^{-2}\right), \mathrm{Lh}=$ Luas lahan $\left(\mathrm{m}^{2}\right)$ dan $\mathrm{Ld}=$ Luas daun $\left(\mathrm{m}^{2}\right)$.

Efisiensi pengunaan radiasi surya merupakan nisbah antara energi yang digunakan untuk membentuk bahan kering dengan total energi surya yang diterima selama masa pertumbuhan (Handoko et al., 2010). Persamaan yang digunakan adalah $\varepsilon=\mathrm{dw} /$ Qint dimana $\varepsilon=$ Efisiensi pemanfaatan radiasi surya $\left(\mathrm{g} \mathrm{MJ}^{-1}\right), \mathrm{dw}=$ penambahan biomassa tanaman $\left(\mathrm{g} \mathrm{m}^{-2}\right)$ dan Qint $=$ Intersepsi radiasi surya $\left(\mathrm{MJ} \mathrm{m}^{-2}\right)$. Pengamatan komponen agronomi meliputi 
pengukuran tinggi tanaman, jumlah daun, bobot kering tanaman serta pengamatan produksi yang meliputi bobot biji tanaman $(\mathrm{g})$, dan bobot 1,000 biji dilakukan pada saat panen.

\section{HASIL DAN PEMBAHASAN}

\section{Intersepsi Radiasi Surya}

Intersepsi radiasi surya adalah selisih antara radiasi yang sampai di atas tajuk tanaman dengan radiasi yang ditransmisikan yaitu radiasi yang diteruskan sampai di bawah tajuk tanaman. Nilai radiasi yang sampai pada tajuk tanaman akan mengalami reduksi pada setiap lapisan daun sehingga sebagian radiasi akan diintersepsi. Nilai intersepsi radiasi surya berfluktuasi mengikuti radiasi global yang ada di atas tajuk tanaman (Gambar 1). Intersepsi radiasi berkorelasi dengan dengan umur tanaman dengan pola hubungan kuadratik yaitu saat fase vegetatif maksimal, nilai intersepsi radiasi cenderung sama bahkan diakhir umur tanaman cenderung menurun. Intersepsi radisasi matahari tanaman dipengaruhi oleh sudut datang matahari, sifat spektral kanopi, indeks luas daun, ukuran daun, bentuk daun, angin, dan fototropisme. Variabel yang sering digunakan untuk memprediksi intersepsi radiasi surya adalah indeks luas daun. Parameter lain yang memiliki peranan dalam mendukung efisiensi penangkapan cahaya tanaman kedelai adalah luas daun trifoliate, tebal daun, jumlah polong, klorofil dan kerapatan trikoma, sehingga intersepsi radiasi ini erat kaitannya dengan produksi biomassa tanaman (Muhuria, 2007).

Intersepsi radiasi surya (Qint) oleh tajuk tanaman dipengaruh oleh nilai index luas daun (ILD) (Gambar 2). Peningkatan nilai ILD secara nyata diikuti oleh nilai Qint yang dihitung menggunakan persamaan hukum Beer. Semakin tinggi nilai ILD maka radiasi yang diredam (k) juga semakin tinggi sehingga nilai radiasi transmisi menjadi berkurang. Peningkatan intersepsi radiasi dan RUE dipengaruhi oleh struktur kanopi, dimana semakin tinggi nilai ILD maka koefisien pemadaman tajuk juga semakin tinggi (Handoko et al., 2010; Ceotto et al., 2013).

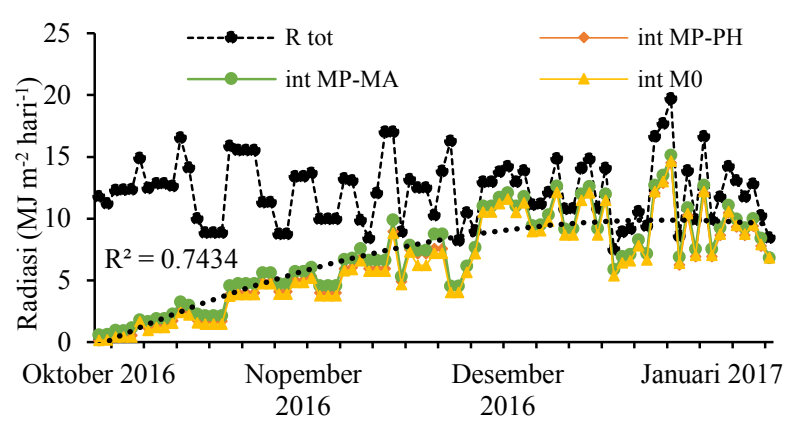

(A) Tanpa naungan

\section{Radiasi yang Dipantulkan oleh Permukaan Mulsa}

Proporsi radiasi total (global radiation) dipengaruhi oleh kondisi atmosfer. Pada kondisi berawan tebal radiasi matahari yang diteruskan ke permukaan menjadi lebih sedikit. Hal ini terjadi karena radiasi matahari terhambat oleh adanya tutupan awan sehingga terjadi perubahan arah dan reduksi oleh air dan zat endapan di atmosfer. Efek dari radiasi diffuse mempengaruhi stomata dan RUE pada tanaman (Li et al., 2016). Energi radiasi matahari yang diteruskan ke tanaman akan mengalami pengurangan seiring perjalanannya menuju ke permukaan tanah. Radiasi yang sampai pada tanaman akan diintersepsi dan direfleksikan oleh tajuk serta ada juga yang ditransmisikan menuju ke permukaan tanah.

Penggunaan mulsa mampu meningkatkan reflektivitas dan penerimaan radiasi matahari pada tanaman. Nilai radiasi yang dipantulkan oleh pemukaan mulsa berfluktuasi mengikuti radiasi global yang ada di atas tajuk tanaman (Gambar 3). Trend yang terbentuk berbanding terbalik dengan trend atau kecenderungan pola nilai intersepsi radiasi yaitu terjadi penurunan nilai radiasi yang dipantulkan oleh mulsa setiap minggu setelah tanam. Penurunan tersebut disebabkan pertumbuhan tinggi dan jumlah daun sehingga radiasi tereduksi oleh kanopi tanaman. Karena sifat determinate, setelah tanaman mencapai vegetatif maksimal, struktur kanopi cenderung tidak mengalami perubahan yang signifikan sehingga radiasi yang dipantulkan cenderung stabil.

Radiasi yang dipantulkan oleh tiap jenis mulsa yang digunakan pada masing-masing perlakuan naungan berbeda nyata. Pada awal setelah tanam jenis mulsa metalik mempunyai persentase pantulan yang lebih tinggi dibandingkan dengan mulsa perak hitam, namun setelah memasuki umur tertentu, terjadi penurunan persentase radiasi yang dipantulkan oleh mulsa metalik pada kondisi normal tanpa naungan. Pada kondisi ternaungi penggunaan mulsa metalik memberikan radiasi pantulan yang lebih besar dibandingkan dengan mulsa perak hitam. Adanya lapisan perak metalik yang terkandung dalam mulsa membuat radiasi yang terpantul lebih besar sehingga menyebabkan tanaman dapat memaksimalkan radiasi tambahan dengan

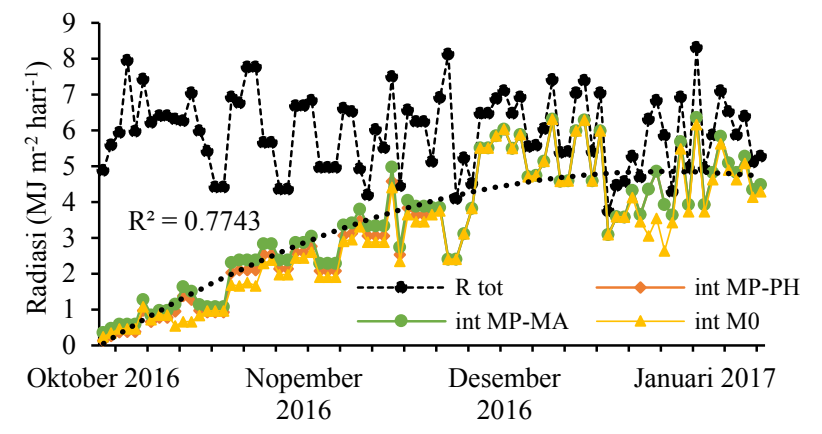

(B) Naungan $50 \%$

Gambar 1. Variasi harian nilai intersepsi radiasi surya tanaman kedelai. Mulsa perak hitam $(\diamond$ MP-PH), Mulsa metalik $(\bullet$ MP-MA), Tanpa mulsa $(\boldsymbol{\wedge}$ M0), Radiasi di atas tajuk $(\bullet$ R.tot $)$ 


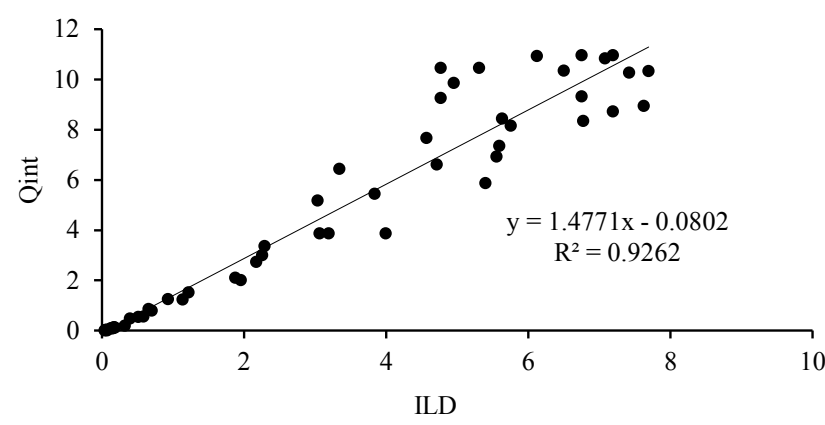

Gambar 2. Hubungan antara index luas daun (ILD) dengan intersepsi radiasi (Qint) dihitung menggunakan Hukum Beer pada tanaman kedelai

adanya radiasi yang dipancarkan oleh permukaan mulsa. Selain pengaruhnya terhadap perubahan nilai intersepsi radiasi oleh tanaman, radiasi yang dipantulkan oleh permukaan mulsa diduga memberikan dampak tersendiri terhadap morfologi, fisiologi, dan produksi tanaman.

\section{Respon Pertumbuhan dan Produksi Tanaman}

Analisis ragam gabungan memperlihatkan pengaruh yang bervariasi; mulsa dan naungan berpengaruh nyata terhadap peubah tinggi tanaman, jumlah daun, produksi dan berat kering total tanaman (Tabel 1). Kurangnya radiasi matahari yang diterima pada kondisi ternaungi mengakibatkan tanaman mengalami etiolasi. Selain pengaruhnya terhadap tinggi tanaman, naungan juga menyebabkan penurunan jumlah daun. Jumlah daun pada kondisi tanpa naungan cenderung lebih banyak dibandingkan pada kondisi ternaungi. Hal ini terjadi karena radiasi tersedia lebih banyak sehingga memungkinkan tanaman memaksimalkan penerimaan radiasi dan mengonversi energi untuk membentuk bagian-bagian tanaman melalui pembelahan dan perpanjangan sel untuk peningkatan pertumbuhan tanaman.

Tinggi tanaman dan jumlah daun nyata dipengaruhi oleh naungan (Kesumawati et al., 2012). Selain itu, naungan juga mempengaruhi adaptasi morfo-fisiologi daun pada kedelai (Kisman et al., 2008). Penggunaan mulsa mampu

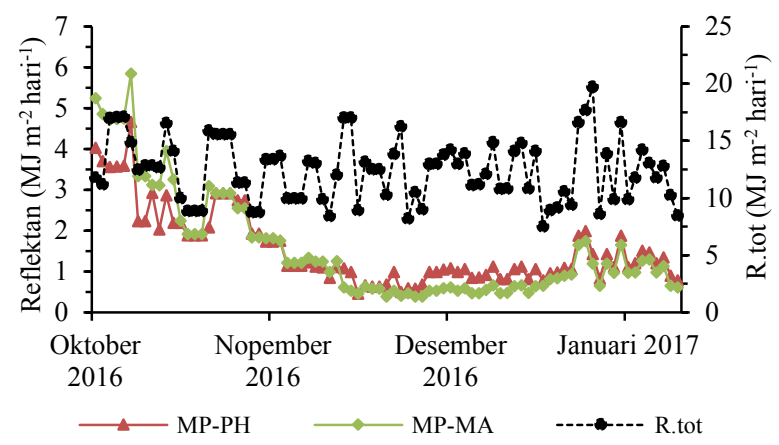

(A) Tanpa naungan mempengaruhi perubahan pertumbuhan tanaman (Tabel 2). Jumlah daun akibat adanya distribusi radiasi oleh perlakuan mulsa meningkat sekitar $10 \%$ dari kondisi tanpa mulsa pada masing-masing naungan.

Penggunaan mulsa pada kondisi ternaungi menunjukkan peningkatan berat kering yang nyata sedangkan tanaman yang tidak menggunakan mulsa mengalami penurunan berat kering yang sangat nyata pula. Hal ini disebabkan pada kondisi cahaya rendah, tanaman mengalami penurunan laju fotosintesis (Sopandie et al., 2003; Sulistyowati et al., 2016). Tanaman dengan mulsa jenis metalik memiliki nilai berat kering tertinggi dan berbeda nyata dengan jenis mulsa perak hitam pada masingmasing naungan.

Perubahan-perubahan pertumbuhan pada tanaman mempengaruhi produksi saat panen. Pada kondisi normal, mulsa perak hitam menghasilkan berat biji per tanaman yang lebih tinggi daripada mulsa metalik (Gambar 4). Pada kondisi ternaungi mulsa metalik memberikan hasil yang lebih tinggi dibandingkan dengan mulsa perak hitam. Hal ini mengindikasikan bahwa pada kondisi radiasi yang rendah (ternaungi) tanaman bisa memaksimalkan sebaran radiasi dari mulsa metalik yang memiliki daya refleksi lebih tinggi. Pada mulsa perak hitam, adanya permukaan hitam pada sisi bawah diduga memberikan pengaruh terhadap keseimbangan iklim mikro tanah sehingga pada kondisi normal hasil yang diperoleh lebih baik dibandingkan dengan mulsa metalik.

Produksi tanaman ditentukan oleh partisi dan akumulasi biomassa tanaman (Salvagiotti, 2008). Produksi per tanaman mengalami kenaikan $17 \%$ dan 34\% masing-masing untuk mulsa metalik dan perak hitam pada kondisi tanpa naungan sedangkan pada naungan 50\% meningkat sebesar 39\% dan $33 \%$ (Tabel 2). Mulsa metalik menghasilkan bobot 1,000 biji lebih baik dibandingkan dengan kontrol pada masingmasing naungan (Gambar 4). Hasil biji sangat berkorelasi dengan efisiensi penggunaan radiasi (RUE) (Adeboye et al., 2016). Perbedaan hasil antara tanaman kedelai yang menggunakan mulsa metalik dan perak hitam pada kondisi teraungi dan tidak ternaungi diduga dipengaruhi oleh faktor penyinaran. Penyinaran yang berlebih menghasilkan total biomassa yang lebih tinggi akan tetapi produksi polong menjadi rendah (Taufik dan Sundari, 2012).

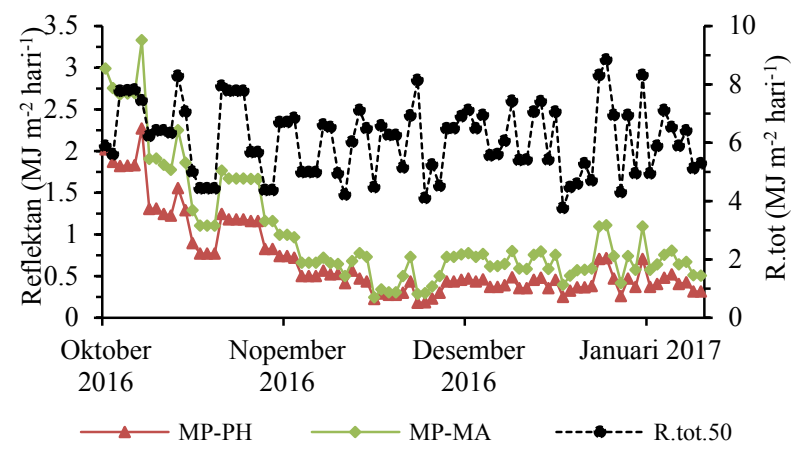

(B) Naungan $50 \%$

Gambar 3. Variasi harian nilai radiasi yang dipantulkan permukaan mulsa terhadap tanaman kedelai. Mulsa perak hitam ( MP-PH), Mulsa metalik $(\diamond \mathrm{MP}-\mathrm{MA})$, Radiasi di atas tajuk $(\bullet$ R.tot $)$ 
Tabel 1. Analisis ragam gabungan pengaruh naungan $(\mathrm{N})$, mulsa $(\mathrm{M})$ dan interaksi $(\mathrm{NxM})$ terhadap respon morfologi dan produksi pada tanaman kedelai

\begin{tabular}{lccc}
\hline $\begin{array}{l}\text { Peubah } \\
\text { pengamatan }\end{array}$ & $\begin{array}{c}\text { Naungan } \\
(\mathrm{N})\end{array}$ & $\begin{array}{c}\text { Mulsa reflektif } \\
(\mathrm{M})\end{array}$ & $\begin{array}{c}\text { Interaksi } \\
(\mathrm{NxM})\end{array}$ \\
\hline Tinggi tanaman & $0.004^{*}$ & $0.004^{*}$ & $0.005^{*}$ \\
Jumlah daun & $0.011^{*}$ & $0.000^{*}$ & $0.001^{*}$ \\
Produksi biji per tanaman & 0.225 & $0.000^{*}$ & $0.002^{*}$ \\
Bobot 1,000 biji & $0.047^{*}$ & $0.014^{*}$ & 0.919 \\
Berat kering total tanaman & $0.002^{*}$ & $0.000^{*}$ & $0.001^{*}$ \\
\hline
\end{tabular}

Keterangan: $(*)$ nyata pada $\mathrm{P} \leq 0.05$; veg $=$ fase vegetatif; gen $=$ fase generatif

Tabel 2. Respon tinggi tanaman, jumlah daun dan berat kering pertanaman kedelai terhadap interaksi perlakuan

\begin{tabular}{lcc}
\hline Peubah pengamatan & Tanpa naungan & Naungan \\
\hline Tingi tanaman (cm) & $\bar{X}$ & $\bar{X}$ \\
Mulsa perak hitam & & $58.51 \mathrm{a}$ \\
Mulsa metalik & $46.16 \mathrm{c}$ & $53.86 \mathrm{~b}$ \\
Tanpa mulsa & $45.06 \mathrm{c}$ & $56.65 \mathrm{a}$ \\
\hline Jumlah daun & $45.71 \mathrm{c}$ & $11.41 \mathrm{~d}$ \\
Mulsa perak hitam & & $12.68 \mathrm{c}$ \\
Mulsa metalik & $15.06 \mathrm{~b}$ & $11.10 \mathrm{~d}$ \\
Tanpa mulsa & $17.33 \mathrm{a}$ & $20.73 \mathrm{~d}$ \\
\hline Bobot kering tanaman $(\mathrm{g})$ & $13.78 \mathrm{c}$ & $22.52 \mathrm{c}$ \\
Mulsa perak hitam & & $15.69 \mathrm{e}$ \\
Mulsa metalik & $30.02 \mathrm{~b}$ & $32.34 \mathrm{a}$ \\
Tanpa mulsa & $21.03 \mathrm{~d}$ & \\
\hline
\end{tabular}

Keterangan: Angka yang diikuti huruf yang sama pada masing-masing baris dan kolom menunjukkan tidak berbeda nyata berdasarkan uji DMRT pada $\alpha=5 \%$

\section{Efesiensi Penggunaan Radiasi (RUE)}

Efisiensi penggunaan radiasi matahari merupakan kemampuan tanaman dalam mengonversi energi menjadi biomassa. Biomassa merupakan respon tanaman terhadap penyerapan radiasi oleh tajuk tanaman (Handoko et al., 2010). Radiasi yang tereduksi oleh naungan menyebabkan ketersediaan radiasi untuk tanaman menjadi berkurang sehingga besaran radiasi yang akan dikonversi menjadi biomasa menjadi lebih rendah.

Berdasarkan gradient intersepsi radiasi surya terhadap biomassa terlihat bahwa penggunaan mulsa dapat meningkatkan nilai RUE (Gambar 5). Pada kondisi tanpa naungan nilai RUE yang diperoleh untuk mulsa perak hitam, mulsa metalik dan tanpa mulsa berturut-turut adalah $1.55 \mathrm{~g} \mathrm{MJ}^{-1}, 1.81 \mathrm{~g} \mathrm{MJ}^{-1}, 1.31 \mathrm{~g} \mathrm{MJ}^{-1}$, dan $1.86 \mathrm{~g} \mathrm{MJ}^{-1}, 1.97$ $\mathrm{g} \mathrm{MJ}^{-1}, 1.72 \mathrm{~g} \mathrm{MJ}^{-1}$ pada naungan 50\%. Dari nilai RUE yang diperoleh terlihat bahwa mulsa reflektif mampu menambah distribusi radiasi pada tanaman sehingga meningkatkan efisiensi penggunaan radiasi baik untuk kondisi tanpa naungan maupun pada kondisi ternaungi.
Nilai RUE tanaman kedelai sekitar $1.44 \mathrm{~g} \mathrm{MJ}^{-1}$ (Singer et al., 2011). Ketika tingkat akumulasi biomassa dan $\mathrm{N}$ berkisar antara 45.6 sampai $64.3 \mathrm{~g} \mathrm{~m}^{-2}$ hari ${ }^{-1}$ dan 1.43 sampai $2.08 \mathrm{~g} \mathrm{~N} \mathrm{~m}^{-2}$ hari $^{-1}$, nilai RUE berkisar antara 1.46

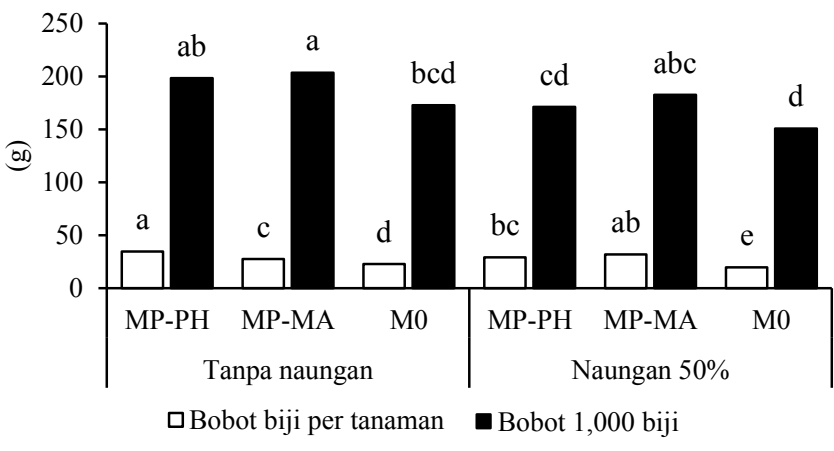

Gambar 4. Bobot biji per tanaman dan bobot 1,000 biji terhadap nilai kontrol (M0) pada tanaman kedelai. Mulsa perak hitam (MP-PH), Mulsa metalik (MP-MA) dan Tanpa mulsa (M0) 


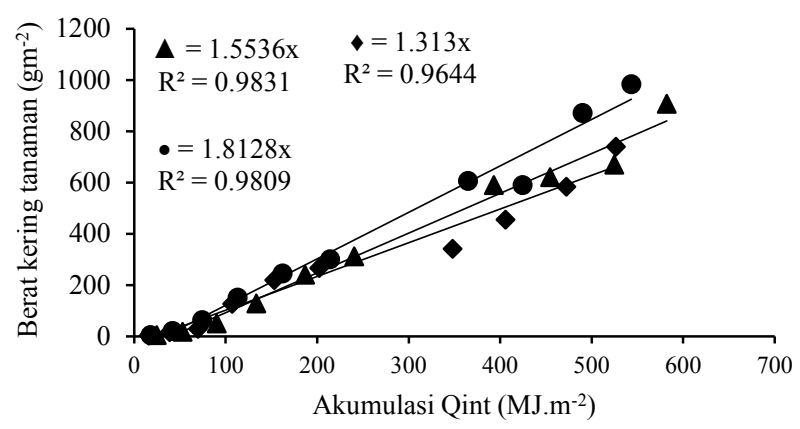

(A) Tanpa naungan

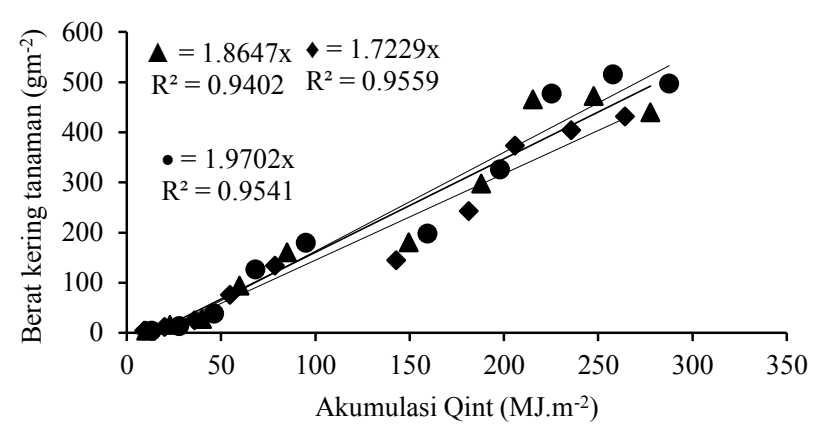

(B) Naungan $50 \%$

Gambar 5. Efisiensi penggunaan radiasi ( $\varepsilon$ ) pada naungan $0 \%$, mulsa perak hitam ( $\mathrm{AP}-\mathrm{PH})$, mulsa metalik ( MP-MA), dan tanpa mulsa $(\diamond \mathrm{M} 0)$

sampai $1.89 \mathrm{~g} \mathrm{MJ}^{-1}$ (Roekel dan Purcell, 2014). Nilai RUE dan intersepsi PAR menjadi biomassa juga dipengaruhi oleh jumlah populasi (Liu et al., 2017), jarak tanam (Wang et al., 2015) dan jenis kultivar kedelai yang digunakan (Schneider et al., 2016).

\section{KESIMPULAN}

Defisit radiasi matahari yang disebabkan adanya naungan menghambat pertumbuhan dan produksi biji tanaman. Pada kondisi radiasi matahari rendah akibat naungan, penggunaan mulsa mampu memberikan pengaruh yang positif terhadap intersepsi radiasi matahari, efisiensi penggunaan radiasi matahari, struktur kanopi, indeks luas daun (ILD), pertumbuhan dan produktivitas tanaman. Intersepsi radiasi matahari dan kemampuan tanaman untuk mengkonversi energi matahari menjadi biomassa melalui efisiensi penggunaan radiasi (RUE) meningkat nyata dengan adanya penggunaan mulsa. Nilai RUE yang diperoleh sekitar 1.3 sampai $1.9 \mathrm{~g} \mathrm{MJ}^{-1}$.

\section{DAFTAR PUSTAKA}

Adeboye, O.B., B. Schultz, K.O. Adekalu, K. Prasad. 2016. Impact of water stress on radiation interception and radiation use efficiency of soybeans (Glycine max L. Merr.) in Nigeria. Braz. J. Sci. Technol. 3:1-7.

Ceotto, E., M. D. Candilo, F. Castelli, F.W. Badeck, F. Rizza, C. Soave, V. Marletto. 2013. Comparing solar radiation interception and use efficiency for the energy crops giant reed (Arundo donax L.) and sweet sorghum (Sorghum bicolor L. Moench). Field Crops Res. 149:159-166.

Feng, Y., S. Huang, R. Gao, L. Weiguo, T. Yong, W. Xiaochun, W. Xiaoling, W. Yang. 2014. Growth of soybean seedlings in relay strip intercropping systems in relation to light quantity and red:far-red ratio. Field Crops Res. 15:245-253.

Gitelson, A.A., J.A. Gamon. 2015. The need for a common basis for defining light-use efficiency: Implications for productivity estimation. Remote Sens. Environ. 156:196-201.

Handoko, I., T. Kodarsih, A. Ariyani. 2010. Koefisien pemadaman tajuk dan efisiensi penggunaan radiasi surya pada tanaman kentang (Solanum tuberosum L.) varietas Granola di Galudra, Cianjur, Jawa Barat. J. Agromet. 24:27-42.

Kesumawati, E., E. Hayati, M. Thamrin. 2012. Pengaruh naungan dan varietas terhadap pertumbuhan dan hasil tanaman stroberi (Fragaria sp.) di dataran rendah. J. Agrista. 16:14-21.

Kisman, Trikoesoemaningtyas, Sobir, N. Khumaida, D. Soepandie. 2008. Pola pewarisan adaptasi kedelai (Glycine max Merr.) terhadap cekaman naungan berdasarkan karakter morfo-fisiologi daun. Bul. Agron. 36:1-7.

Koester, R.P., J.A. Skoneczka, R.T. Cary, B.W. Diers, E.A. Ainsworth. 2014. Historical gains in soybean (Glycine max Merr.) seed yield are driven by linear increases in light interception, energy conversion , and partitioning efficiencies. J. Exp. Bot. 65:33113321.

Li, T., J. Kromdijk, E. Heuvelink, F.R. van Noort, E. Kaiser, L.F.M. Marcelis. 2016. Effects of diffuse light on radiation use efficiency of two anthurium cultivars depend on the response of stomatal conductance to dynamic light intensity. Front. Plant Sci. 7:1-10.

Liu, X., T. Rahman, F. Yang, C. Song, T. Yong, J. Liu, C. Zhang, W. Yang. 2017. PAR interception and utilization in different maize and soybean intercropping patterns. PLoS ONE. 12:1-7.

Mejias, P.B. 2012. Effect of crushed glass, used as a reflective mulch, on pinot noir performance. Thesis. Lincoln Universiy. Christchurch-New Zaeland.

Meyer, G.E., E.T. Paparozzi, A.E. Walter-Shea, E.E. Blankenship, S.A. Adams. 2012. An investigation of 
reflective mulches for use over capillary mat systems for winter-time greenhouse strawberry production. Amer. Soc. Agric. Biol. Engineers 28:271-279.

Muhuria, LA. 2007. Mekanisme fisiologi dan pewarisan sifat toleran kedelai (Glycine max L) terhadap intensitas cahaya rendah. Disertasi. Institut Pertanian Bogor. Bogor.

NASA Earth Observatory. 2008. Climate and Earth's Energy Budget. https://earthobservatory.nasa.gov/Features/ EnergyBalance/page4.php.[Juli 2017].

Roekel, R.J.V., L.C. Purcell. 2014. Soybean biomass and nitrogen accumulation rates and radiation use efficiency in a maximum yield environment. Crop Sci. 54:1189-1196.

Salvagiotti, F., D.J. Miralles. 2008. Radiation interception, biomass production and grain yield as affected by the interaction of nitrogen and sulfur fertilization in wheat. Eur. J. Agron. 28:282-290.

Schneider, J.R., B.O. Caron, E.F. Elli, F.Schwerz, A.P. Rockenbach, T.D. Engroff. 2016. Conversion efficiency of photosynthetically active radiation in soybean cultivars during planting seasons. Aust. J. Basic Appl. Sci. 10:209-214.
Singer, J.W., D.W. Meek, T.J. Sauer, J.H. Prueger, J.L. Hatfield. 2011. Variability of light interception and radiation use efficiency in maize and soybean. Field Crops Res. 121:147-152.

Sopandie, D., M.A. Chozin, S. Sastrosumarjo, T. Juhaeti, Sahardi. 2003. Toleransi padi gogo terhadap naungan. Hayati 10:71-75.

Sulistyowati, D., M.A. Chozin, M. Syukur, M. Melati, D. Guntoro. 2016. Karakter fotosintesis genotipe tomat senang naungan pada intensitas cahaya rendah. J. Hort. 26:181-188.

Taufik, A., T. Sundari. 2012. Respons tanaman kedelai terhadap lingkungan tumbuh. Buletin Palawija 23:13-26.

Wang, R., T. Cheng, L. Hu. 2015. Effect of wide-narrow row arrangement and plant density on yield and radiation use efficiency of mechanized direct-seeded canola in Central China. Field Crops Res. 172:42-52.

White, J.W., J. Izquerdo. 1993. Physiology of yield potential and stress tolerance. In A.V. Schoonhoven, O. Voysest (Eds.). Common Beans: Research for Crop Improvement. CAB International, Wallingford, UK. 